\title{
Rural Water Supply and Sustainable Development in Nigeria: A Case Analysis of Akwa Ibom State
}

\author{
Enefiok E. Ibok ${ }^{1}$, Ekong E. Daniel ${ }^{2, *}$ \\ ${ }^{1}$ Department of Public Administration, Akwa Ibom State University, Uyo, Akwa Ibom State, Nigeria \\ ${ }^{2}$ Faculty of Social and Management Sciences, Akwa Ibom State University, Uyo, Akwa Ibom State, Nigeria \\ *Corresponding author: ekongdan@yahoo.com
}

Received August 21, 2014; Revised November 13, 2014; Accepted November 21, 2014

\begin{abstract}
Generally, the level of water supply in Akwa Ibom State is poor. The situation is pathetic in the rural areas where water is either scarce or costly when it is available. Many trek several kilometres every morning and evening in search of water while others depend on polluted water from ponds, stream, rainwater and floods for domestic use, thereby increasing health hazard. After eighteen (18) years of the establishment of the Akwa Ibom State Rural Water Supply and Sanitation Agency (AKRUWATSAN), coupled with the huge Akwa Ibom State Government expenditure on the provision of water in the rural areas of the State, the situation does not seem to improve. What factors are responsible for the disproportionate water situation in the rural areas? This study attempted to identify the factors. The reports of Akwa Ibom State Water Supply and Sanitation Agency (AKRUWATSAN) 2012 - 2013 were reviewed to determine the number of rural water projects undertaken in the study area during the period of the report. Structured interviews were conducted with a total of 249 randomly selected respondents in 83 purposively selected communities. The study revealed that Akwa Ibom State Government has developed a total of 83 mini-water projects in the same number of rural communities to boast the supply of clean and safe water in 13 Local Government Areas during the study period. The study has discovered lack of maintenance, lack of community participation, lack of coordination and co-operation among the stakeholders, political factor, inefficient monitoring, and poor attitude towards public property to be the factors responsible for the incommensurate rural water situation in the study area. Rain water harvesting with its various advantages among other strategies has been recommended.
\end{abstract}

Keywords: rural water, sustainable development, Nigeria, Akwa Ibom State

Cite This Article: Enefiok E. Ibok, and Ekong E. Daniel, "Rural Water Supply and Sustainable Development in Nigeria: A Case Analysis of Akwa Ibom State." American Journal of Rural Development, vol. 2, no. 4 (2014): 68-73. doi: 10.12691/ajrd-2-4-2.

\section{Introduction}

Safe water and sanitation are the essential indicators of sustainable development. The United Nations General Assembly, at its Millennium Meeting in 2000, established eight Millennium Development Goals (MDGs) with targets to be achieved by 2015, with the aim of speeding up poverty alleviation and socio-economic development. The MDGs were elaborated and endorsed by the intergovernmental community at the World Summit on sustainable Development, convened in Johannesburg. It was strongly believed that water quality management contributes both directly and indirectly to achieving the targets set out in all eight MDGs, although it is most closely tied to specific targets of the goal No. 7 which is to ensure environmental sustainability such as:

i. Integrate the principles of sustainable development into country policies and programme and reverse the loss of environmental resources. ii. Halve by 2015 the proportion of people without sustainable access to safe drinking water and basic sanitation.

iii. Significantly reduce biodiversity loss by 2020: and

iv. Achieve significant improvement in the lives of at least 100 million slum dwellers by 2010. In all these water quality can be used as indicators to demonstrate progress toward the targets of the MDGs [4].

Adequate water supply is synonymous with development whether it is urban or rural. In Nigeria, water supply lags behind other countries that are considerably poorer in Africa. For example, of the $50 \%$ that dwells in rural areas, $60-65 \%$ has no access to portable water. In the rural areas or in the city peripheries water is either scarce or costly when it is available. Many trek several kilometres every morning and evening in search of water while others depend on polluted water from ponds, springs, lakes, rivers, streams, shallow boreholes or floods for domestic use. Time for productive activities are wasted in search of water. Also, inadequate water supply has resulted to food shortage and water borne diseases [11], [9]. To contain these problems, this paper therefore analyses efforts by Akwa Ibom State government in 
ensuring good and safe water supply especially in rural areas for sustainable development.

\section{The Problem}

Akwa Ibom State Government recognises that clean, safe and portable water is essential to human life. Nevertheless, rural water supply in the State remains deplorable. Various State Government Administrations, past and present recognise the rural water supply problem. It is an undeniable fact that potable water is in short supply in the rural areas of the State. The second, third, fourth and subsequent National Development plans have consistently made reference to the inadequacy of rural water supplies. To be sure, the Second National Development Plan (1970-1974) states thus:

In the rural areas, where inadequacy or absence of good water supply has been found to have a direct bearing on the spread of certain water-borne diseases, the strategy also would be to improve the quality and source of water supplies in these areas in order to reduce the incidence of such diseases [8].

Rural dwellers in Akwa Ibom State obtain their water supplies from a variety of sources, including wells, rain water, streams, rivers, lakes etc. By and large, the quality of water from these sources proves grossly poor. Water supply in the state is categorised into urban and rural water supplies. Urban supply is undertaken by Akwa Ibom Water Company. Rural water provision is undertaken by the Ministry of Rural Development through its agency known and called Akwa Ibom State Rural Water Supply and Sanitation Agency (AKRUWATSAN).

The responsibilities of the agency as enshrined in part 1 section 6 of 1996 Akwa Ibom State Rural Water Supply and Sanitation Agency Edit amended are as follows:

a. Provision of accessible potable water for every rural community in Akwa Ibom State.

b. Ensuring that the water supplied to every rural community is clean and healthy.

c. Ensuring that the water is supplied at affordable cost.

d. Establishment, control and maintenance of both old and new water works in the rural areas.

e. Prevention and control of pollution of water resources and supply in every rural community.

f. To liaise with the local government and rural communities in promotion of sanitation [1].

After eighteen (18) years of the establishment of the Agency, coupled with the huge government expenditure on the provision of water in the rural areas of the State, the situation does not seem to improve. What factors are responsible for the disproportionate water situation in the rural areas? This study attempts to identify the factors responsible in order to remove the impediments to sustainable development in this sector.

\section{The Study Area (Akwa Ibom State, Nigeria)}

The study was conducted in Akwa Ibom State. Akwa Ibom State is one of the thirty-six States in the Federal Republic of Nigeria with the Population of over 3.5 million people [10]. It was created on $23^{\text {rd }}$ September,
1987. There are 31 Local Government Areas including Uyo the State Capital. The State is strategically located at the Southeastern corner of Nigeria between latitudes $4^{\circ} 30^{1}$ and $5^{\circ} 33^{1}$ North and longitudes $7^{\circ} 30^{1}$ and $8^{\circ} 25^{1}$ East (see Figure 1). It is sandwiched between Abia and Rivers States to the West, Cross River State to the East, Abia State to the North and Atlantic Ocean to the South. The mean annual temperature of $80^{\circ} \mathrm{F} / 27^{\circ} \mathrm{C}$ and annual relative humidity of between 70 to 80 percent, coupled with mean annual rainfall of 3017 millimeters favor quick plant growth [6]. The area falls within the sedimentary area of Nigeria. It is drained by three major rivers namely: Imo River, Kwa Iboe River and Cross River. Approximately, $75 \%$ of the State is located on coastal plain sand and alluvium which covers the whole of the southern, central and partially the northern parts, while the sandstone of the Ameke Formation and the underlying Imo Shale cover the remaining 25\% [13]. According to "Reference [5]", published geological maps of the Geological Survey of Nigeria 1:250,000 sheet 79 (Umuahia) indicates that Akwa Ibom State consists of stratigraphic units ranging from Maastrichtian to Plaistocane. Within this framework, four distinctive units are recognized. Three of these belong to the coastal Plain Sands and Beach Ridge Complex and the remaining one to the Shay Fancies of the North East of the State. The lithology of the area, which is more than $80 \%$ sand and sandstone, is very favourable for the storage and extraction of groundwater. The coastal plain sands are the main aquifer in the area. The northern boundary of the aquifer is formed by the impervious clays and shales of the Ameke and Imo Shale formation. The Southern boundary is the sea, where it is believed that the aquifer continue below the sea to form a connection between fresh water and brackish water. The total thickness of the aquifer in the area may be up to 500 meters [13].

\section{The Concept of Sustainable Development}

The satisfaction of human needs and aspirations is the major objective of development. The important needs of greater numbers of people in developing countries for food, clothing, shelter, water etc are not being met, and beyond their basic needs the people have legitimate aspirations for an improved quality of life. Therefore, a world in which poverty and inequality are endemic will always be prone to ecological and other crisis. Sustainable development requires meeting the basic needs of all and extending to all the opportunity to satisfy their aspirations for a better life [14].

Sustainable development, according to "Reference [3]" is development that meets the needs of the present generation without compromising the ability of future generations to meet their own needs. "Reference [2]", sees sustainable development as humanity's ability to survive by means of the rational use of renewable resources, by refraining from disrupting the ecosystem or overexploiting natural resources and by refraining from activities that destroy cultures or societies and instead allow them to reach their potential.

Generally, sustainable development has to do with participatory development, human development and 
environmental protecting. In the contexts of this study the emphasis is on environmental dimension which entails protections of the natural resources especially water bodies while it is being presently exploited so that the future generations can also meet their needs from the same resources. Progress along this dimension requires practices as well as the cautious use of equipment and chemical to avoid contaminating water sources. In providing safe and clean water supply in rural areas of Akwa Ibom State, the government and other agencies involved worked in conjunction with Ministry of Environment to supply safe and clean water to rural communities in the State.

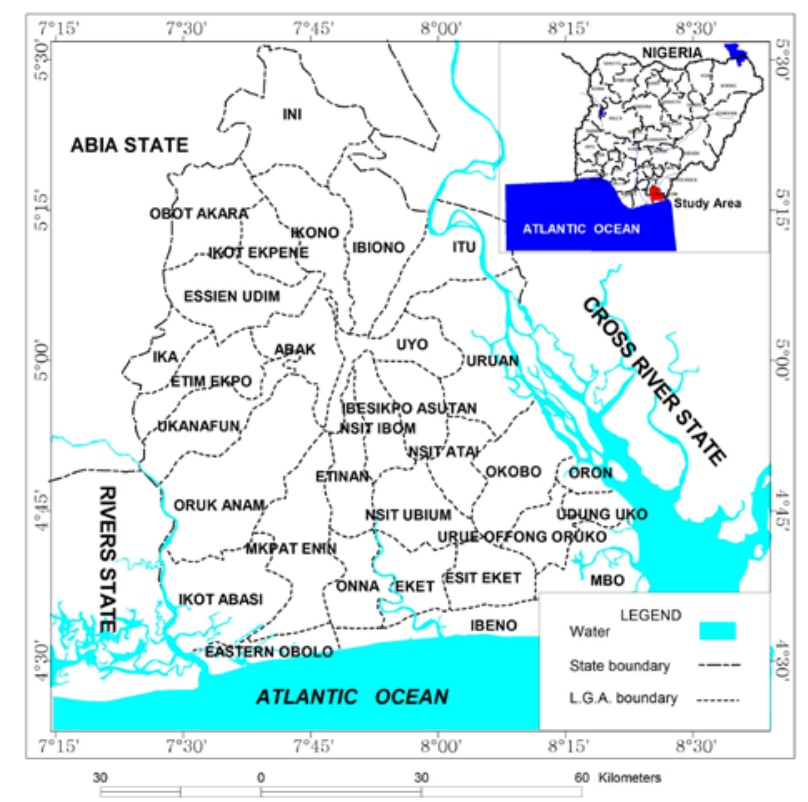

Figure 1. Akwa Ibom State - The Study Area

\section{Historical Development of Rural Water Supply in Nigeria}

A bold attempt at ensuring water supply dates back to the colonial era when the first ten year plan $(1944-1956)$ included in its overall budget of about $5.7 \%$ total expenditure for the sector. With this, concrete open wells were constructed under the supervision of Public Works Department (PWD), of the Regional Governments who were responsible for providing safe water to the rural communities. Since independence several National Rural Water Supply Programmes have been undertaken by Federal Government, States Governments, Local Governments, World Bank, UNDP and UNICEF to develop rural water supply [12].

In the mid 1970s the World Bank financed Agricultural Development Programme (ADP) which has covered the whole State with diverse names such as Cross River Agricultural Project (CRAP), Akwa Ibom Agricultural Projects (AKADEP) etc. Rural Water supply component assumed a major part of these projects. In 1981, UNICEF included rural water supply and sanitation in Nigeria country programme from which more than 22 states are benefitting. From 1989 to 1992, the UNDP operated rural water projects focusing on the Local Government with perceived advantages of being closer to the rural communities. Through this programme, the rural water and sanitation sector strategy and action plan was developed.

It is worth saying that serious efforts at addressing rural water supply and sanitation issues began with the on-set of the International Drinking Water Supply and Sanitation Decades (IDWSSD) in 1981 which established universal target. This was followed by the World Summit for Children in 1990, which established goals of universal access to safe water and sanitation and complete eradication of guinea worm [7]. Some of the agencies for rural water supply in Nigeria are:

i. UNICEF Assisted State water and sanitation projects (1981 - 2010).

ii. National Borehole programme (1981 - 1986).

iii. Directorate of Food, Roads, and Rural Infrastructure (DFRRI).

iv. Japanese International Cooperation Agency’s (JICA) Rural Water Supply Projects 1992 - 1994.

v. Petroleum Trust Fund (PTF) Rural Water Supply and Sanitation (1996 - 1999).

vi. Improved Access to Water Supply and Sanitation Programme (2000 - 2001).

vii. European Union (EU) Water and Sanitation Programme 2002 - 2009.

viii. Water Aid's Rural Water Supply and Sanitation Programme (1996 - 2010).

ix. Development of Local Manufacture of Hand Pumps (1988 - 2010) [11].

Despite these frantic efforts, the country is still lacking behind at providing safe water for its citizenry especially those in the rural areas. The focus of this study is on Akwa Ibom State Government efforts in providing safe water supply to the rural communities in the past few years.

\section{Methodology}

The study reviewed the reports of Akwa Ibom State Water Supply and Sanitation Agency (AK-RUWATSAN) 2012 - 2013. This was done basically to determine the number of rural water projects undertaken in the study area during the period of the report. Also, structured interviews were conducted with a total of 249 randomly selected respondents in 83 purposively selected communities. Through the interviews it was possible to gain the understanding of the current water situation in the study area. It also enabled assessment of the peoples' perception regarding the various water projects and the real needs of the people.

\section{Findings/Discussion}

The study reveals that Akwa Ibom State Government has developed a total of 83 mini-water projects in the same number of rural communities to boast the supply of clean and safe water in 13 Local Government Areas (see Table 1). These projects represent concerted effort on the part of the State Government towards improved rural water supply. They are indications that Akwa Ibom State Government appreciates that clean and safe water supply not only in quantity, but also in qualitative terms has been the foundation of sustainable development. Suffice to say 
that, the government's efforts in ensuring sustainable development via rural water supply have generated positive impact on the socio-economic development of the rural people. The various improved water supply outlets have served as good sources of income to many households. They have encouraged the cultivation of small gardens, irrigation of vegetables, livestock watering, cottage industries such as brick-making, etc. They have also helped to reduce to the minimum the incidence of water borne and related diseases in the rural areas. Moreover, the establishment of cottage industries enhances employment generation. Also, rural water supply has allowed rural women ample time to undertake economic activities instead of the usual long treks and time consuming search for water. Children too are spared the long treks for water therefore attend school regularly and punctually in line with the free and compulsory education for children in the State. Above all, there has been improved food security, discouraged rural - urban drift and balanced development in rural and urban areas of the State.

Table 1. Locations of Mini Water Project by Akwa Ibom State Rural Water Supply and Sanitation Agency (AKRUWATSAN 2012 -2013)

\begin{tabular}{|c|c|c|}
\hline $\mathrm{S} / \mathrm{N}$ & Water Projects/Location & Local Government \\
\hline 1 & $\begin{array}{l}\text { 1. Itak Ikot Akpandem } \\
\text { 2. Nung Ukim, } \\
\text { 3. Ibiaku Ata, } \\
\text { 4. Ikot Nseyen, } \\
\text { 5. Nung Imoh } \\
\text { 6. Nkwot, Ediene Ward } 9 \\
\text { 7. Itak }\end{array}$ & Ikono \\
\hline 2. & $\begin{array}{c}\text { Ikot Ebre, } \\
\text { Afaha Offiong, } \\
\text { Nsidung, Ikot Ita } \\
\text { Obotim, } \\
\text { Ikot Ekong, } \\
\text { Obotim Ikot Atim. }\end{array}$ & Nsit Ibom \\
\hline 3. & $\begin{array}{l}\text { 1. Ikot Ebido, } \\
\text { 2. Ikot Mbonde, } \\
\text { 3. Obio Atai, } \\
\text { 4. Attan Offot, } \\
\text { 5. Obot Obom Etoi, } \\
\text { 6. Ifa Ikot Abia Ntuen, } \\
\text { 7. Mobile Base Idoro }\end{array}$ & Uyo \\
\hline 4. & $\begin{array}{c}\text { Mbak Obio, } \\
\text { Mbak, } \\
\text { Mbiatok, } \\
\text { Ikot Andem, } \\
\text { Oku Iboku, } \\
\text { Okpolo Ididep, } \\
\text { Ibiaku Itam, } \\
\text { Ekit Itam }\end{array}$ & Itu \\
\hline 5. & $\begin{array}{l}\text { 1. Ikot Obio Ndua, } \\
\text { 2. Ikot Ebre, } \\
\text { 3. Afaha Ikot Obio Nkan, } \\
\text { 4. Ikot Ide } \\
\text { 5. Mbiakpong, } \\
\text { 6. Ikot Ikan, } \\
\text { 7. Ikot Akpasin, } \\
\text { 8. Edem Ibiok, } \\
\text { 9. Ikot Iko, } \\
\text { 10. Nsidung, } \\
\text { 11. Oboyo Ikot Ita, } \\
\text { 12. Obotim } \\
\text { 13. Ikot Ekong }\end{array}$ & Ibesikpo Asutan \\
\hline 6. & $\begin{array}{c}\text { Midim, } \\
\text { Ibong Ikot Akpan Otoro } \\
\text { Ediene, } \\
\text { Offot Abak, } \\
\text { Otoro, } \\
\text { Oku Abak, } \\
\text { Manta Abak }\end{array}$ & Abak \\
\hline 7. & Amamong & Okobo \\
\hline
\end{tabular}

\begin{tabular}{|c|c|c|}
\hline & $\begin{array}{c}\text { Offi, } \\
\text { Atabong, } \\
\text { Ikot Okiuso, } \\
\text { Itak Ekim } \\
\text { Oti-Oro, } \\
\text { Okopedi, } \\
\text { Akpabasi Ayak }\end{array}$ & \\
\hline 8. & $\begin{array}{c}\text { Ikot Umoh, } \\
\text { Ikot Udobia, } \\
\text { Ikot Udo } \\
\text { Afaha Obo } \\
\end{array}$ & Etinan \\
\hline 9. & $\begin{array}{l}\text { Ikot Essien Enang, } \\
\text { Itak Ikot Udo, } \\
\text { Ikot Abia Idem } \\
\text { Ikot Enwang, } \\
\text { Abiakpo } \\
\text { Ikot Obio Nting, } \\
\text { Ikot Obong Idung } \\
\end{array}$ & Ikot Ekpene \\
\hline 10. & $\begin{array}{l}\text { Ikot Abia Ufok, } \\
\text { Ikot Etefia Minya, } \\
\text { Nung Ukim III, } \\
\text { Ikot Abasi Akpan, } \\
\text { Ikot Ekpe }\end{array}$ & Mkpat Enin \\
\hline 11 & $\begin{array}{c}\text { Ede Obuk } \\
\text { Usung Inyang, } \\
\text { Urua Udoinyang, } \\
\text { Ikot Ebok, } \\
\text { Ikot Usekong } \\
\end{array}$ & Eket \\
\hline 12. & $\begin{array}{c}\text { Iwukem } \\
\text { Etuk Uruk Eshiet } \\
\text { Utu Etim Ekpo, } \\
\text { Edem Akai }\end{array}$ & Etim Ekpo \\
\hline 13 & $\begin{array}{c}\text { Iwochang } \\
\text { Ukpenekang } \\
\end{array}$ & Ibeno \\
\hline
\end{tabular}

Source: AKRUWATSAN Annual Report, 2014

Sadly though, despite government huge expenditure in the provision of affordable and portable water in our rural communities, the study has revealed absence of sustainability. The study has discovered the factors responsible for the incommensurate rural water situation in the study area. The factors are discussed as follows.

\subsection{Lack of Maintenance}

The findings of the study show that $64 \%$ of the projects were not functioning. Many of them the pumping machines broke down few days after commissioning and they have remained moribund since then.

\subsection{Lack of Community Participation}

Findings show that almost all (94\%) of the rural water projects the rural people were not consulted. This has created a lot of problem as water projects were cited based on political patronage and party affiliation. This top-down approach has not gone down well with the people who openly displayed their anger by vandalizing the project after commissioning.

\subsection{Lack of Coordination and Co-operation among the Stakeholders}

The study finding reveal duplication of same project in 20 communities. These communities enjoy similar water project provided by State Government, Federal Government, International Agencies, Cooperate bodies and community efforts. It turn out to be that some communities are favoured with three to four water stations while others have at all. Still some other communities that needed more were neglected. 


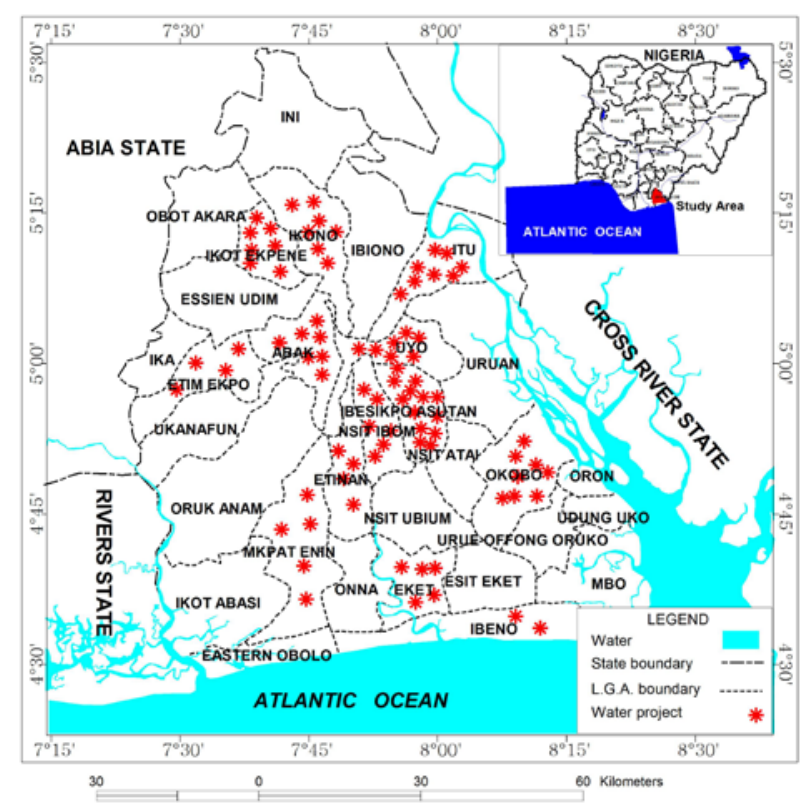

Figure 2. The distribution of water projects in the Study Area

\subsection{Political Factor}

Findings show that some mini-water stations have been located on political grounds without due consideration to geological factors. This means that considerations were not given to environmental impact assessment. Some of the rural communities have experienced project abandonment because of wrong location. Associated with this is the award of contract to contractors who lack technical drilling experience, have no sufficient equipment, staff or financial resources to undertake the work. Political patronage has been responsible for failure of some water projects effort in the state.

\subsection{Inefficient Monitoring}

Although there is monitoring unit to monitor each mini water station, but this is hampered by inadequate staff strength and skills, weak institutional mechanism, logistical and budget constraints, due to inadequate resources and framework. This therefore hampered feedback on monitoring and evaluation findings.

\subsection{Poor Attitude towards Government Property}

The study findings reveal nonchalant attitude of the people toward public property. People are careless in the use of the water and the installations. It was observed that some water taps were left open for the water to run wastefully.

\section{Conclusion}

Water is at the centre of economic and social development. It is vital to maintain health, grow food, managed the environment, and create jobs. Despite the importance of water, it is estimated that over 783 million people in the world are still without access to improved water sources and even more are without access to consistent safe drinking water. No wonder world leaders rank water as one of their top critical issues [15].

The issue of potable water supply is very important to Akwa Ibom State Government in the light of the increasing health awareness among rural public which main objective is to improve safe drinking water to the rural population. This informed government decision in ensuring rural water supply via various agencies notably Akwa Ibom Rural Water Supply and Sanitation (AKRUWATSAN). The effort of government in meeting rural water is evidenced by the data provided which revealed that with the emergence of democratic governance in 1999 to 2013, a total of over 400 mini water stations have been provided to various rural communities in the state. Although, these were met with some challenges, however, it is hope that with more determination by the different tiers of government in partnership with external support agencies and private sector with the cooperation of the people more can be done to enhance effective and efficient rural water supply for sustainable development not only in Akwa Ibom State, but also in Nigeria and Africa at large.

\section{Recommendations}

Despite Akwa Ibom State government efforts in providing safe and clean water to the rural communities in the state, there were some factors that hindered it effectiveness and efficiency. Based on this, the study therefore provides the following recommendations:

i. That government should involve and motivate communities in the policy formulation, execution and maintenance of the project.

ii. That citing of water station should be fairly located devoid of political and primordial sentiment.

iii. There should be effective monitoring of the project to ensure consistency in water supply.

iv. That government should provide effective training for staff of AK- RUWATSAN to enhance their performance.

v. That government should ensure good water quality standard and service efficiency.

vi. There should be impact assessment before commencement of such project to ensure sustainability.

vii. There should be proper coordination between state government and other agencies responsible for rural water supply to avoid lopsidedness and duplication of efforts.

viii. That government should embark on sensitization programme for rural people to see government project in their domain as their project which must be zealously protected.

ix. More funds should be committed to this sector to ensure effective coverage and prompt service delivery.

$\mathrm{x}$. Above all, it should be understood that sustainable development in all areas of life cannot be achieved without considerations to the environment. Since the study area is blessed with abundant and regular supply of rain water, the rural dwellers should be encouraged to continue the practice of rain water harvesting. This is the method of collecting rain water and conserving it for later use. The water thus stored in tanks, containers etc can be used for household purposes such as livestock feeding, washing of vehicles, washing of toilets, washing of clothes, watering 
home gardens etc. Rain water harvesting has various advantages; it is available at no cost; it preserves the clean drinking water from safe sources strictly for drinking purposes; it recharges the groundwater; it protects the soil from leaching thus preserving the environment and enhancing sustainability.

\section{References}

[1] Akwa Ibom State Rural Water Supply and Sanitation Agency (AK-RUWATSAN) Executive Summary, 2000, p. 2.

[2] Ballara, M. Women and Literacy. Women and World Development Series of the Joint UN/NCO Group on Women and Development. London: Zed Books Ltd. 1991.

[3] Brundtland Commission (1987). Report of the World Commission on Environment and Development. United Nations.

[4] Carr, G. M., Neary, J. P. (2006). Water Quality for Ecosystem and Human Health. Canada: UN GEMS/Water Programme Office.

[5] Daniel, E., Ekpe, N., Okurebia, S. (2014). Sustainable Development and Utilization of the Red/Brown Earth (Laterite) in South-Eastern Nigeria. Caribbean Journal of Science \& Technology, Vol. 2: pp. 464-470.

[6] Daniel, E. (2012). Inter-Urban Transportation Patterns in a SubRegion of Nigeria: An Analysis, Germany: Lap Lambert Academic Publishing.
[7] Department for International Development (2001) Sustainable Livelihoods Guidance Sheets. Department for International Development, London. Available at www.livelihoods.org.

[8] Federal Republic of Nigeria, Second National Development Plan, 1970-1974, Lagos: Federal Ministry of National Planning (The National Planning Office).

[9] MacDonald, A. M., Davies, J., Calow, C. L. and Chilton, P. J. (2005). Developing Groundwater: A Guide for Rural Water Supply. United Kingdom: ITDG Publishing.

[10] Mbat, D., Ibok, E and Daniel, E. (2013). Exxon-Mobil and Corporate Social Responsibility in Akwa Ibom State, Nigeria: Past and Present. Public Policy and Admnistration Research Vol. 3, No. 3: pp. 21-28.

[11] Nwankwoala, A. O. (2011). "Localizing the Strategy for Achieving Rural Water Supply and Sanitation in Nigeria." African Journal of Environmental Science and Technology, 5 (13), 29, pp. 1170-1176.

[12] Onugbu, A., Sara, S. G. (2003). "Rural Water Supply and Hand pump Development in Nigeria". 29 $9^{\text {th }}$ WEDL International Conference towards the Millennium Development Goals. Abuja, Nigeria, pp. 145-148.

[13] Peters, S. W. (1989) Geology of Akwa Ibom State: Physical Background, Soil and Land Use and Ecological Problems, Akwa Ibom State Government Press.

[14] www.un-documents.net/oct-02.htm. Retrieved 25-05-2014.

[15] www.worldbank.org/en/topic/watersupply. Retrieved 25-5-2014. 